\title{
THREATENED FISHES OF THE WORLD: Squalius castellanus Doadrio, Perea and Alonso, 2007 (Cyprinidae)
}

\author{
Carla Sousa-Santos ${ }^{1 *}$, Joana Isabel Robalo ${ }^{1}$, Ana Pereira ${ }^{1}$, Ignacio Doadrio \\ ${ }^{1}$ Eco-Ethology Research Unit, ISPA Universitary Institute, Rua Jardim do Tabaco 34, 1149-041 Lisbon, Portugal \\ ${ }^{2}$ Museo Nacional de Ciencias Naturales, CSIC, José Gutiérrez Abascal 2, 28006 Madrid, Spain \\ * Corresponding author, E-mail: carla.santos@ispa.pt
}

\begin{tabular}{|c|c|}
\hline ARTICLE INFO & ABSTRACT \\
\hline $\begin{array}{l}\text { Received: } 12 \text { March } 2014 \\
\text { Received in revised form: } 5 \text { May } 2014 \\
\text { Accepted: } 5 \text { May } 2014 \\
\text { Available online: } 7 \text { May } 2014\end{array}$ & $\begin{array}{l}\text { Squalius castellanus is an endemic cyprinid fish from the lberian Peninsula, } \\
\text { with a distribution area restricted to the River Tagus (Gallo sub-basin). This } \\
\text { species is critically endangered mainly due to pollution and fluctuations of } \\
\text { the water regime. }\end{array}$ \\
\hline
\end{tabular}

\section{Keywords:}

Squalius castellanus

Endemic species

Critically endangered fish

\section{COMMON NAME}

Bordallo del Tajo (Spanish) - Figure 1.

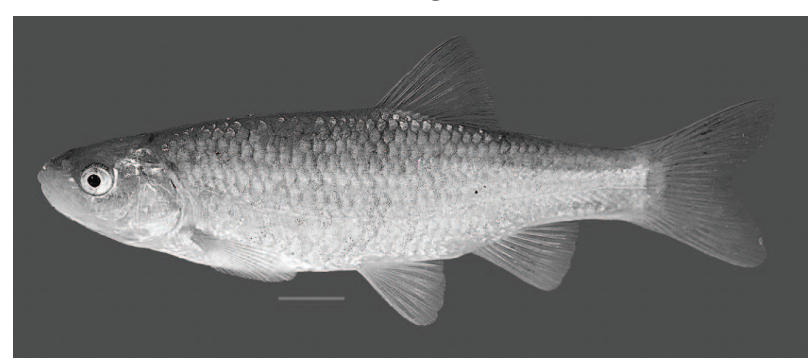

Fig 1. Squalius castellanus (Photo credit: Ignacio Doadrio)

\section{CONSERVATION STATUS}

Critically Endangered according to the IUCN guidelines (Doadrio et al., 2011).

\section{IDENTIFICATION}

This species has a silvery yellowish body with up to $200 \mathrm{~mm}$ TL, presents 39-42 scales in the lateral line, 7 scales above the lateral line and 3 scales below the lateral line (Doadrio et al., 2007). Contrasting to the remaining Squalius species,
S. castellanus has eight branched rays in the dorsal and anal fins, a wide third infraorbital bone and a pharyngeal teeth formula of $5+2 / 5+2$ (Doadrio et al., 2007). S. castellanus diverged from its sister species Squalius carolitertii in the Pliocene, about 3.8 My ago (Doadrio et al., 2007).

\section{DISTRIBUTION}

This species is endemic to Spain and occurs in the Upper Tagus, namely in the River Gallo and its tributaries.

\section{ABUNDANCE}

During monitoring actions performed during 2009 and 2011, only one specimen was captured, indicating that this species may be close to extinction (Doadrio et al., 2011).

\section{HABITAT AND ECOLOGY}

Typically occurs in deep, cold water habitats with sparse aquatic vegetation.

\section{REPRODUCTION}

Males show nuptial tubercles during the reproductive sea- 
son which occurs between April and June (Doadrio et al., Sažetak 2011).

\section{THREATS}

S. castellanus is mostly endangered by pollution and fluctuations of the water regime. Restocking of salmonid populations may also have a negative impact in the River Gallo where a fish farm of Oncorhynchus mykiss contaminates the river with organic and chemical wastes. Fish escapes to the wild may also negatively impact $S$. castellanus since adult salmonids may prey juveniles and compete for space and food.

\section{CONSERVATION RECOMMENDATIONS}

An ex-situ conservation program should be implemented to prevent extinction, together with in-situ measures aiming for habitat conservation, improvement of water quality and availability, and regulation of the salmonid restocking actions.

\section{ACKNOWLEDGMENTS}

This study was funded by project CGL2010-15231-BOS (MNCN-CSIC) and by FCT - Portuguese Foundation for Science and Technology (partially FEDER funded), under the multiannual financing programme UI\&D 331/94 and the project PTDC/AAC-CLI/103110/2008. C. Sousa-Santos was supported by a Post-doctoral grant from FCT (SFRH/ BPD/29774/2006).

\section{UGROŽENE VRSTE RIBA U SVIJETU: Squalius castellanus Doadrio, Perea i Alonso, 2007 (Cyprinidae)}

Squalius castellanus je endemska ciprinidna vrsta ribe s Iberijskog poluotoka, s distribucijskim područjem ograničenim na rijeku Tagus (podsliv rijeke Gallo). Ova je vrsta kritično ugrožena uglavnom zbog zagađenja i fluktuacija vodnog režima.

Ključne riječi: Squalius castellanus, endemska vrsta, kritično ugrožena riba

\section{REFERENCES}

Doadrio, I., Perea, S., Alonso, F. (2007): A new species of the genus Squalius Bonaparte, 1837 (Actinopterygii, Cyprinidae) from the Tagus River basin (central Spain). Graellsia, 63, 1, 89-100.

Doadrio, I., Perea, S., Garzón-Heydt, P., González, J. L. (2011): Ictiofauna continental española - bases para su seguimiento. Gobierno de España, Ministerio de Medio Ambiente y Meio Rural y Marino, Madrid. 610 p. 